\title{
Perception of Millennial Generation about Global Issue of Citizenship in College Student Community of Democratia Sebelasmaret University
}

\author{
Muhammad Yogi Guntoro ${ }^{1}$, Dewi Gunawati ${ }^{2}$, Rusnaini ${ }^{2}$ \\ ${ }^{1}$ Postgraduate Student of Civic Education, Sebelas Maret University, Indonesia \\ ${ }^{2}$ Postgraduate Lecturer of Civic Education, Sebelas Maret University, Indonesia
}

\begin{abstract}
Citizenship status also refers to the competence or capacity of a person to participate in building and contributing to society. The citizenship competencies are knowledge, attitudes, and skills of a person in participating and responsible in the life of the community and state at the local, national, and international levels. The citizens must take responsibility to make a better world in this era much issue in global space in civic discussions room student give the literacy about global issue of citizenship to build a perception in citizens. This research is a qualitative study carried out in the collage student community of democratia Sebelas Maret University. Millennial are invited to study various issues regarding climate change and they study these problems using ecological citizenship as their scientific basis, namely through ecological citizenship as a means of changing thinking about the urgency of the importance of handling climate change from the perspective of citizens. With increasing literacy on global justice, students will understand the importance of their role as part of global society in helping to realize the importance of mutual peace that global justice is a shared responsibility.
\end{abstract}

\section{Keywords \\ global issue of citizenship; ecological citizenship; gldbal justice}

\section{Introduction}

According to Kalidjernih in (Education of Citizenship and Insights of Nationality to the Vision of Indonesia 20251 By: Rusnaini2, nd) Citizenship is not merely related to the relations of the state and citizens but it refers to a status that expresses the capacity or competence of a person as a member of society. Illustrate that citizenship status also refers to the competence or capacity of a person to participate in building and contributing to society. The citizenship competencies are knowledge, attitudes, and skills of a person in participating and responsible in the life of the community and state at the local, national, and international levels. Citizens have the fundamental goal to move the life of democracy following the state of the social-political environment. The involvement of citizens as the subject of democracy will give birth to a strong citizen character (Mukmin, 2019).

There has been a shift in educational discourse and practice. Overcoming this problem is related to the relevance of education and learning in solving global problems in the social, political, cultural, economic and environmental fields. The role of education moves beyond the development of cognitive knowledge and skills to build values, soft skills, and attitudes among students. Education is expected to facilitate international cooperation and facilitate social transformation in innovative ways towards a more just, peaceful, tolerant, inclusive, safe and sustainable world. (UNESCO, 2016) 
Sugihartono (2007) suggests that the perception is ability to translate sensory stimulus or process for translating stimulus into human sensory organs. So in other words the perception of a person's ability to interpret information on their fishing and concluded in his thinking. This research take millennial generation because millennial generation is big part in society and the millennial generation will bring the society in the better future or worst future.

The conception of citizenship has one idea which is that the framework needed for citizenship is sovereignty, a territorial state. The legal status of citizens is basically a formal expression of membership in a government that has certain boundaries where citizens enjoy the same rights and run their political agency.

In other words, citizenship, both as a legal status and as an activity, is considered to presuppose the existence of a political community that is bounded by territory, which extends over time and is the focus of shared identity. In the past twenty years, this premise has been watched closely. A number of phenomena, related to 'globalization', have eroded the conception of traditional citizenship. Transnational economic exchanges, competition and communication, as well as high rates of migration, cultural and social interaction, have shown how vague that borders are has become and led people to fight for the relevance and legitimacy of state sovereignty.

According to Kalidjernih in (Pendidikan Kewarganegaraan Dan Wawasan Kebangsaan Menuju Visi Indonesia 20251 Oleh: Rusnaini2, n.d.) "Citizenship is not merely related to the relations of the state and citizens but it refers to a status that expresses the capacity or competence of a person as a member of society." can illustrate that citizenship status also refers to the competence or capacity of a person to participate in building and contributing to society. The citizenship competencies are knowledge, attitudes, and skills of a person in participating and responsible in the life of the community and state at the local, national, and international levels.

Rusnaini (Rusnaini R, Sebelas, \& Changes, 2016) formulated that the Global issue of citizenship was formulated into 5 main issues of global citizenship, namely: "1) climate change, 2) global justice and social harmony, 3) human rights as security issues, 4) global peace and global governance, and 5) the change and continuation of civilizations.

The issue of climate change is a central issue that we must look for a solution such as a statement put forward by UN Secretary-Ban KI Moon (Overview of Climate Change, 2005) Climate change, and how we address it, will define us, our era and ultimately the global legacy we leave for future generations.

Climate change is not new. The global climate is always changing. Millions of years ago, parts of the world that are now warmer, were once covered by ice, and in recent centuries, average temperatures have fluctuated seasonally, as a result of fluctuations in solar radiation, for example, or due to volcanic eruptions periodically.

Stanford encyclopedia of Philosophy di said that increased interest concerning issues of global justice has also coincided with enhanced interest in the place and value of nationalism. These explorations also track contemporary events such as nationalist clashes which have spilled over into widespread suffering (notably in the former Yugoslavia and Rwanda), increased calls for national self-determination to carry considerable weight, such as in-state recognition for Palestinians or Tibetans, and also in the case of secession (prominently, Quebec).

Based on Rusnaini's formula, the writer takes a number of issues to limitation the problem, namely the urgent problem in the world 1) climate change, 2) global justice in 
perception from millennial generation in college student community of democratia Sebelas Maret University.

\section{Research Method}

This research is a qualitative study carried out in the college student community of democratia Sebelas Maret University. Interviews, observations and document studies are data collection techniques that are used in accordance with the opinion of HB Sutopo (2002) that "the source of data in qualitative research can be humans, events, or activities, places or locations, objects, pictures or records, documents or files". The Test validity data using data triangulation and method triangulation. Research Subject Taking Techniques with purposive sampling or sampling technique with certain considerations. While the data analysis technique uses 1) Data reduction, which summarizes, chooses the main things, focuses on the important things, 2) Presentation of data that is presenting data to understand what happened during the research, 3) drawing conclusions is verification or concludes strong evidence to support the next stage of data collection. Then the research procedure is through the preparation, implementation, and preparation of reports.

\section{Discussion}

According to Toha (2003), the factors that influence one's perception are as follows:

a. Internal factors: feelings, attitudes and characteristics of individuals, prejudices, desires or hopes, attention (focus), learning processes, physical states, psychiatric disorders, values and needs as well as interests, and motivation.

b. External factors: family background, information obtained,

Solomon in prasetijo paper says, the perception of the process where the sensation received by someone sorted and selected, then set and finally interpreted (Prasetijo \& Ihallauw, 2005: 67). The relationship between perception and sensation is clear. Sensation is part of perception. Even so, interpreting the meaning of sensory information not only involves sensation but also attention, expectations, motivation and memory (Rachmat, 2005). Through the terminology of generation division, there are some things that can be seen that the current generation has experienced social changes, some things that have changed with the changing times. The things that change according to Kieran Healy (1998: 16) are demographics, economics, and technology.

The following is an explanation according to Kieran Healy in various fields:

\section{Demographics}

The demographic process is driving change at all levels of society, from the most extensive and long-term patterns of development of the global human population to the most recent trends in fertility and immigration. Demographic change is related to institutional and political change: when the family system changes shape, society seeks to influence these patterns through social policy.

2. Economy

The expansion of the digital economy creates many new economic opportunities. Digital data can be used for development purposes and to solve community problems, including those related to SDGs. It can thus help improve economic and social outcomes and be a force for innovation and productivity growth. But positive results are still far from what was expected. Just because digitalization has the potential to support development, any value 
that is realized cannot be distributed fairly. Even if individuals, companies and countries do not - or only partially - take part in the digital economy, they can still be affected indirectly. Workers with limited digital skills will find themselves in the disadvantageous position of dealing with those who are better equipped for the digital economy, powerful local companies will face stiff competition from digitalized domestic and foreign companies, and jobs will be lost due to automation.

\section{Technology}

One of the most significant results of information technology advancements is electronic commerce via the Internet, a new way of doing business. Although only a few years old, he can radically change economic activities and the social environment. Already, it affects large sectors such as communication, finance and retail trade and may develop into fields such as education and health services. This implies seamless application of information and communication technology along the entire value chain of businesses conducted electronically.

Firstly issue in discussion is, issue of climate change has shown that people around the world or the world community, are included in the group risk or risk society. From (Beck, 2007) us know about "effect of climate change generalized. Damage and natural and environmental hazards, news about toxic substances in foodstuffs and consumer goods that threaten - and worse, actually - chemical accidents, poisons or reactors have a devaluing effect that creeps or runs fast and deprivation of rights the property".

Cited from the Ministry of Environment and UNDP (United Nations Development Programme Indonesia, 2007) sources of changes that we are experiencing today due to climate change and that the consequences can be felt by present and future generations. Some things we can expect are:

a. Changes in seasons and rainfall - In recent years farmers in villages on the island of Java have talked about abnormal seasons. the beginning of the rainy season is now 10 to 20 days late and the beginning of the dry season is 10 to 60 days late. Similar shifts have also been felt in various regions in Indonesia. These patterns have the opportunity to continue. In the future, some parts of Indonesia, especially those located south of the equator, may experience a longer dry season and shorter rainy season but with higher rainfall. In addition, the climate is also likely to become increasingly volatile, with more frequent erratic rainfall. Higher temperatures can also dry out the soil, reduce soil water resources, land degradation, and in some cases can lead to desertification.

b. More extreme weather events - We will experience more frequent and more severe coastal storms, and long droughts and high rainfall that can trigger landslides.

c. Rising sea levels- As a result of sea water melting and melting glaciers and polar ice caps, global warming can cause sea levels to rise between 9 and $100 \mathrm{~cm}$. This increase will accelerate erosion in coastal areas, trigger intrusion of seawater into ground water, damage swamps in coastal areas, and drown small islands.

d. Increased seawater temperature - Warmer seawater can prevent plankton breeding and reduce fish food availability. Some fish species will likely migrate to other regions that offer better temperature and food conditions. Higher temperatures can also damage or 'bleach' coral reefs.

e. Rising temperatures - This will change the patterns of vegetation, and also the spread of insects such as mosquitoes that will be able to survive in areas that were previously too cold for their breeding. 
From exposure to the impacts above climate change can be said is one of the major issues that must be immediately found a solution in the science of citizenship in the know a concept called ecological citizenship. The idea of ecological citizenship related to the environment can shape the personality balance of each individual and society. (Rusnaini, 2015) "Ecological citizenship discusses how humans as individuals who have identified themselves (especially: identity and morality) can adapt to the environment in society, both internal capacity (activities) to accept community authority or externally to shape and become involved in forming constitutive communities ". In the context of ecological citizenship, if we use environmental ethics as a perspective, we will be able to increase our responsibility towards the environment.

As stated Kalidjihrih in (Rusnaini, 2018) Ecological citizenship is an idea where environmental damage and protection of the environment become global issues. This idea can be compared with a movement called environmentalism. The environmentalist movement seeks to raise awareness of the interrelationships between humans and nature that can affect human life patterns and behavior. These environmentalist movements have important implications for the conception of citizenship. They question seriously about the state as the owner of public policy by pointing out that ecological and bioregional measures often do not respect the boundaries outlined.

The Indonesian government is considered to be still less concerned with environmental problems, many Indonesians throughout the region also do not understand that they live in an ecosystem, which with the destruction of one element of the ecosystem will affect other elements of the ecosystem. Keraf dalam (Rusnaini, 2018) stated that nature and all of its contents have dignity and value in the middle and in the community of life on earth. Obligations and responsibilities are based solely on moral considerations that beings in the universe do have values on the basis that they have a dignified life of their own. Therefore, humans must protect and preserve it.

Ecological citizenship has become a topic of global discussion because of the insurmountable damage to the environment and the call for environmental protection. If we relate it to our existence in the world today as a risk society, efforts to protect people from the effects of environmental degradation will become even more significant.

From the above data, students are invited to study various issues regarding climate change and they study these problems using ecological citizenship as their scientific basis, namely through ecological citizenship as a means of changing thinking about the urgency of the importance of handling climate change from the perspective of citizens.

The secondly issue is global justice in the discussion student give more information about global justice. Following the revolutions that Europe shook in the mid-1800s, social justice became a rallying cry for progressive thinkers and political activists. Proudhon, notably, identified justice with social justice, and social justice with respect for human dignity. (Karpov, 2012) The translation of that opinion is that following the revolution that shook Europe in the mid 1800s, social justice became a call for progressive thinkers and political activists. Proudhon, in particular, identifies justice with social justice, and social justice by respecting human dignity.

In an article in the Stanford Encyclopedia of Philosophy it is said that increased interest concerns the issues of global justice has also been coincided with enhanced interest in the place and value of nationalism. These explorations also track contemporary events such as nationalist clashes which have spilled over into widespread suffering (notably in the former Yugoslavia and Rwanda), increased calls for national self-determination to carry sufficient 
weight, such as in state recognition for Palestinians or Tibetans, and also in the case of secession (prominently, Quebec). (https://plato.stanford.edu/entries/justiceglobal/\#WhaTheGloJus quoted 12 December 2019)

The increased interest in the issue of global justice also coincides with an increase in interest in the place and value of nationalism. This exploration also tracks contemporary events such as nationalist clashes that have spilled over into widespread suffering (especially in the former Yugoslavia and Rwanda), increased calls for national self-determination to carry enough weight, such as in-country recognition for Palestine or Tibet, and also in the case separation (striking, Quebec). It can be said that global justice emerged after the Second World War and strengthened when there were many conflicts affecting the world, especially conflicts that were confused with Ethnic, religious and racial issues

The philosophical framework is related to the increasingly prominent phrase "global justice". A distinctive feature of this framework is the focus on the causal and moral analysis of the global institutional order with viable alternatives and alternative backgrounds (What Is Global Justice?, 2019). The criteria will coincide in their emphasis on the question of how well our global institutional order is doing, with regard to human fundamental interests that are important from a moral standpoint. Extending institutional moral analysis abroad, this question focuses on how the main incidences of violence and extreme poverty today, and causes of death and excessive morbidity can be avoided not only through better government behavior, internally and internationally but also far more effective through global institutional reforms which will, among other things, improve such government behavior by modifying government options and the incentives they face.

There is some debate in implementing the global justice paradigm that contradiction is due to the claim that it is relevant for the moral assessment of the global institutional order for how to treat human individuals. This claim can be developed into three more specific and independent challenges ("What Is Global Justice?," 2019).

First, the rules of many governments that are called are based on nothing more than brute strength. Approval from such a ruler, however free and competent is given, cannot be interpreted as agreement by the people they manage to be subdued.

Second, it is widely agreed that human rights cannot be revoked, that humans cannot give up their right not to be tortured or enslaved, their right to participate in politics, or their right to the most basic needs of human survival. To the extent that the current design of global institutional arrangements unexpectedly results in irrevocable rights that are more unfulfilled than can reasonably be avoided, this order cannot be maintained by appealing the agreement of those whose rights cannot be revoked now not fulfilled.

Third, even if we assume that humans can give up their most basic human rights and that less developed citizens have actually done this through their acceptance of the current global institutional order, we still have to ask how it can be allowed to impose this rule in children who are highly represented among those who died due to causes related to poverty.

With increasing literacy on global justice, students will understand the importance of their role as part of global society in helping to realize the importance of mutual peace that global justice is a shared responsibility. 


\section{Conclusion}

As good citizens we bear a shared responsibility that is not only burdened by a single group and also we bear a shared responsibility to realize and protect our earth and our world as a better place to live and therefore as a generation will come millennial must be prepared. Millennial are invited to study various issues regarding climate change and they study these problems using ecological citizenship as their scientific basis, namely through ecological citizenship as a means of changing thinking about the urgency of the importance of handling climate change from the perspective of citizens. With increasing literacy on global justice, students will understand the importance of their role as part of global society in helping to realize the importance of mutual peace that global justice is a shared responsibility.

\section{References}

Beck, U. (2007). Risk Society: Towards a New Modernity. In Sociológia - Slovak Sociological Review. https://doi.org/10.2307/143601

Karpov, Y. V. (2012). Development Through the Lifespan. In Vygotsky's Educational Theory in Cultural Context. https://doi.org/10.1017/cbo9780511840975.009.

Mukmin, B. A., et al. (2019). Citizenship Politics (Reviewing the Meaning of Democracy in Majanggut I Village, Royal District Pakpak Barat Regency). Budapest International Research and Critics Institute (BIRCI-Journal), 354-362.

Pendidikan Kewarganegaraan Dan Wawasan Kebangsaan Menuju Visi Indonesia 20251 Oleh: Rusnaini2. (n.d.). 1-13.

Rusnaini. (2018). Konstruksi Studi-Studi Kewarganegaraan. Kajian Pembelajaran Dan Inovasi Pendidikan, 1-18. Retrieved From Https://Civitas.Uns.Ac.Id/Rusnaini/WpContent/Uploads/Sites/607/2018/08/Konstruksi-Studi-Studi-Kewarganegaraan.Pdf

Rusnaini, R. (2015, November). Global Issues of Citizenship and the Development of Civic Education for University Students in Indonesia. International Conference on Teacher Training and Education.

Rusnaini R, Sebelas, U., \& Changes, G. (2016). Global sssues of citizenship and the development of civic education for university students in Indonesia. 1(1), 636-639.

Sutopo, H. B. (2002). Pengantar Penelitian Kualitaitf. Surakarta: UNS Press.

Yin, Robert K. 2011. Studi Kasus: Desain dan Metode. Rajagrafindo Persada. Jakarta

United Nations Development Programme Indonesia. (2007). Sisi Lain Perubahan Iklim. 120.

What Is Global Justice? (2019). What Is This Thing Called Philosophy?, 68-80. https://doi.org/10.4324/9780203771006-7

https://plato.stanford.edu/entries/justice-global/\#WhaTheGloJus quoted 12 December 2019 